\title{
Implementation of Acceleration of Education Program for Students Special Intelligent in Leading $X$ High School in Jakarta
}

\author{
Herwanto Wanto* \\ Herwanto Psychology Study Program Faculty of Psychology Education, State University of Jakarta \\ *Corresponding author: herwanto.psi@gmail.com
}

\begin{abstract}
This study aims to analyze accelerated education program implementation, especially (1) input (antecedents), (2) process (transactions), and (3) product (outcomes). The samples were determined by purposive with total number forty eight respondents, includes principal, teachers, students, and parents. The method was based on Stake model with qualitative approaches. Data collection used document analysis, in-depth interviews, structured observations and questionnaire, and were analyzed with descriptive qualitative method with program NVIVO 11, then interpreted narratively with research finding percentages. The result shows that accelerated education program implementation are input at $95.53 \%$, but IQ only reaches $40 \%$, and funding only $60 \%$. Besides, process has an average $100 \%$, unfortunately, teacher's interest in teaching only $50 \%$ and evaluation system at $90 \%$. On the other hands, products mean $100 \%$, but national examination (UN) only $70 \%$. This dissertation is expected, could contribute to knowledge on discovery model / paradigm of accelerated education program.
\end{abstract}

Keywords: countenance evaluation, accelerated, giftedness

Cite This Article: Herwanto Wanto, "Implementation of Acceleration of Education Program for Students Special Intelligent in Leading X High School in Jakarta." American Journal of Educational Research, vol. 5, no. 7 (2017): 828-838. doi: 10.12691/education-5-7-20.

\section{Introduction}

Initial observation results, empirical facts in the field show that accelerated education programs held in schools are still found in shortage and require improvement. This is done so that the services provided for students who have the potential and / or special talents are in accordance with the needs of students and lead to the development of their potential optimally even maximal.

In line with the above findings, the authors conducted needs analysis through observation and interviews in some acceleration program organizers in SMA Unggulan DKI Jakarta found gaps experienced by teachers and students such as (1) teachers are too focused to pursue material achievement (emphasis on the cognitive / knowledge ) On the one hand, thus neglecting the education of students' attitudes and behaviors in order to form the character of the students; (2) from the student side too much content of teaching materials, both in terms of the number of subjects and materials so as to inhibit the social-emotional maturity of students. (3) the design of its own curriculum for acceleration classes, (4) provide training to teachers and students of acceleration classes (5) Services for gifted smart students are currently privileged for those already identified, and (6) are still oriented towards school-based giftedness (IQ), not yet oriented towards productive talent (performance Based giftedness).
To that end, the accelerator education program providers allow researchers to evaluate this accelerated program, focusing on the evaluation of the curriculum of the implementation of accelerated education programs for the special intelligent students. Conceptual acceleration, acceleration is given by Pressey (in Hawadi, [30]) as an advancement gained in teaching programs, at a faster time or younger age than conventional ones. Acceleration includes the requirement to avoid the obstacles to demand fulfillment in learning that enables exceptional intelligent students through faster material delivery than the average student's average progress.

Given, more than three decades / thirty years, precisely since 1974 government efforts pioneered educational service programs for students who have the potential of intelligence and special talent in the form of acceleration program policy (acceleration) (MoNE, [11]). Government policies from time to time regarding special education for students who have such potential and / or special talents continue to experience refinement. This is done so that the services provided really fit the needs of students and lead to the development of their potential.

It is estimated that more than $2 \%$ of school-age children, ie more than 1 million the number of intelligent gifted children are special in Indonesia. Treatment of this amount is limited in number (ie about 4,500 children), as well as the quality of learning in accelerated classes at schools designated by the government (Conny R. Semiawan \& Frieda Mangunsong, [68]). 
The condition is supported from the research results Hawadi, et al. (Hawadi, et al., Ministry of National Education, [12]) on the accelerated learning program for Senior High Schools in 16 Provinces in Indonesia which concluded that the program was not considered to have a positive impact on gifted students to develop high intellectual potential. One of the contributing factors is data showing $25.3 \%$ of high school students only have general intelligence that works at below average level and only $9.7 \%$ are classified as students having the potential of intelligence and special talent. It is also reinforced by Wardiman Djojonegoro that experience in various countries percentage and distribution as follows: 1) Gifted students, 2 percent; 2) Fast learners, 12 percent; 3) General student population, 70 percent; 4) Slow learners, 10 percent; 5) Handicapped students, 6 percent (Utami Munandar and Conny Semiawan, [48]).

It means that in almost all grades $25 \%$ more students have below the standard of acceleration program and approximately $10 \%$ are classified as qualified gifted smart special, this is consistent with conditions in various countries that $2 \%$ of students who are classified as intelligent, $12 \%$ Above-average ability, $70 \%$ of students are average in general, $10 \%$ are slow learners and $6 \%$ have learning difficulties.

Another fact is that the accelerated program is not in accordance with existing laws in which special intelligent students still lack special treatment. With this acceleration program, acceleration students feel less social especially when

\section{Theoretical Study}

\subsection{Program Evaluation Concept}

This study uses a program evaluation model developed by Stake (in S. Hamid Hasan, 2008: 206), called the Countenance Evaluation Model. Countenance It means whole or something favored (favorable). Stake program evaluation concept according to James W Popham (1975: 31-34) emphasizes two main activities namely description and assessment / consideration. Evaluation is done through three stages, namely antecedents (preparation or input), transactions (processes) and outcomes (products). This model is taken to focus and to provide a comprehensive understanding of the effectiveness of the process of organizing an accelerated education program. Scriven (in Fitzpatrick, J.L., Sanders, J.R, Worthen, B.R, 2004: 5) defines evaluation as an assessment of the worth or merit of something. Merit is defined as the price or superiority of the evaluan (evaluated), while the meaning of worth (meaning) leads more to the meaning or value of the influence of the evaluation on the environment. Evaluations can not be separated from standards and criteria. If a percentage of the phenomena evaluated indicates success then that status indicates the success of the evaluan.

\subsection{The Program Concept Evaluated}

In accordance with General Provisions Explaining Law Number 20 Year 2003 regarding National Education
System, the Ministry of National Education is obliged to achieve the Vision of National Education as follows: "The realization of the education system as a strong and authoritative social institution to empower all Indonesian citizens to grow into quality human beings So as to be able and proactive to answer the ever changing challenges of the age. In line with the Vision of National Education, the Ministry of National Education is eager for the year 2025 to produce: INSAN INDONESIA SMART AND COMPETITIVE (Kamil Insan / Insan Plenary)" (Renstra Depdiknas 2000-2009, tt: 7).

A. Definisi Acceleration

Understanding acceleration according to Big Indonesian Dictionary (KBBI) Depdikbud, 1997: 18) means: (1) the process of accelerating, (2) speed improvement; Acceleration and (3) speed change rate. Conceptually, the notion of acceleration is given by Pressey (in Hawadi, ed. 2004: 31), as an advance gained in teaching programs, at a faster time or younger age than conventional ones. This definition shows that acceleration includes the requirements to avoid the obstacles to demand fulfillment in learning and also to propose processes that enable students through faster material delivery than the average student progress. From the definition there are three notes. First, there needs to be a steady existence of a collection of materials, tasks, skills, and knowledge requirements of each level of learning. Second, requires a speed of desired and specific progress, through a curriculum suitable for all students. Third, the allegation when compared to peer age, intelligent students will be able to speed up faster through a standard learning program. In general opinion expressed Vialle and Carlton (Depdiknas, 2007: 17-19). There are two educational services for exceptional intelligent students, namely acceleration and enrichment. Acceleration (acceleration) is a program or activity that allows to complete more curriculum materials. While enrichment (enrichment) is a program that allows the expansion and deepening of curriculum materials in general. Educational services for exceptional intelligent students can be enrichment programs and a combination of acceleration-enrichment programs. In this program, students do not solely accelerate the completion time of study at school, but at the same time obtain escalation or enrichment of material with the provision of additional opportunities and learning facilities that are extension / deepening. The provision of accelerated services without escalating or enriching the material is essentially very disadvantageous to the students (Stanley in Semiawan (1b), 1994: 73). Special education for special intelligent gifted students is held in an effort to optimize the development of students' special intelligence potentials to produce superior output (output). To achieve these advantages, the input (input / intake) such as: students, teachers, education services, supporting facilities, management and education process is directed to achieve the objectives of the learning process (standard process).

B. Understanding Intelligent Students

The Unifactor Definition Model proposed by the United States Office of Education (U.S.O.E), (Now Department of Education of the United States), cited Marland in 1972, defined gifted and talented: "Gifted and talented children. d. Model of Stake Program Evaluation 


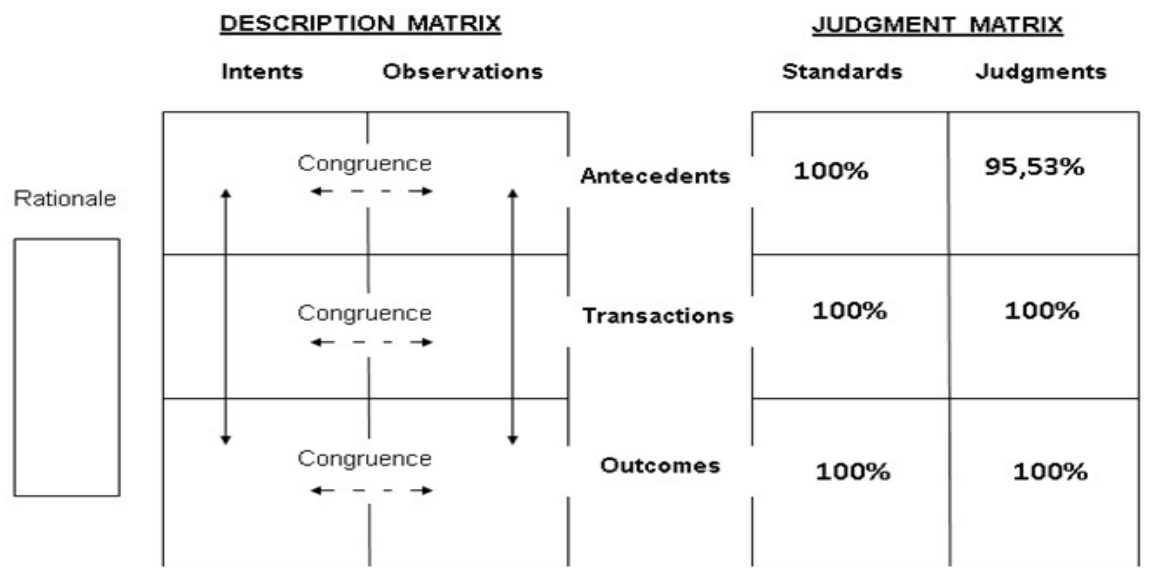

Figure 1. Basic Countenance Model

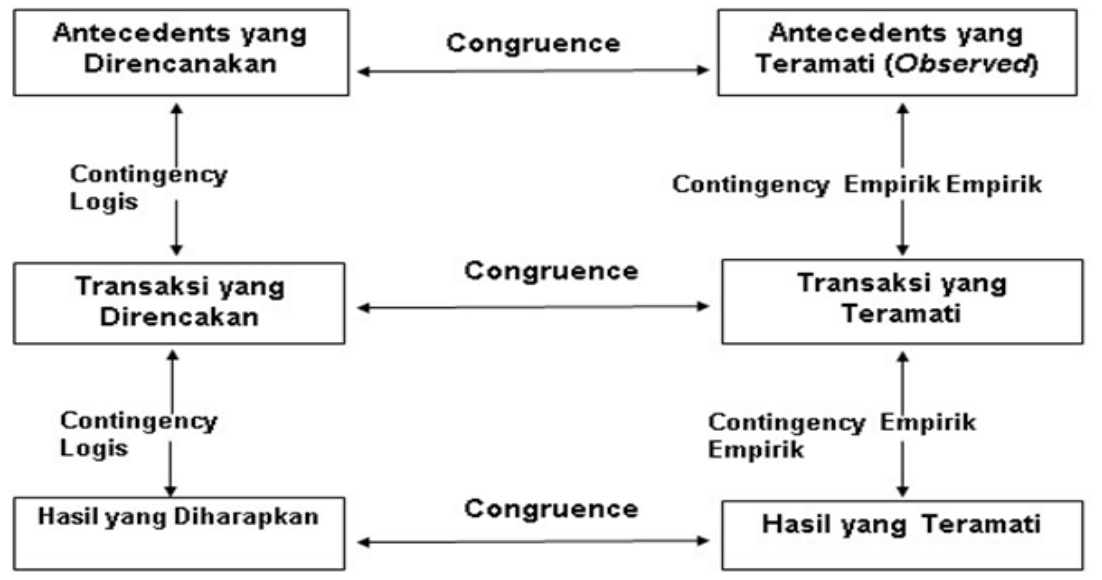

Figure 2. Data Processing Model Description

Theoretical Digest used in the Implementation of Learning Program in Acceleration Class

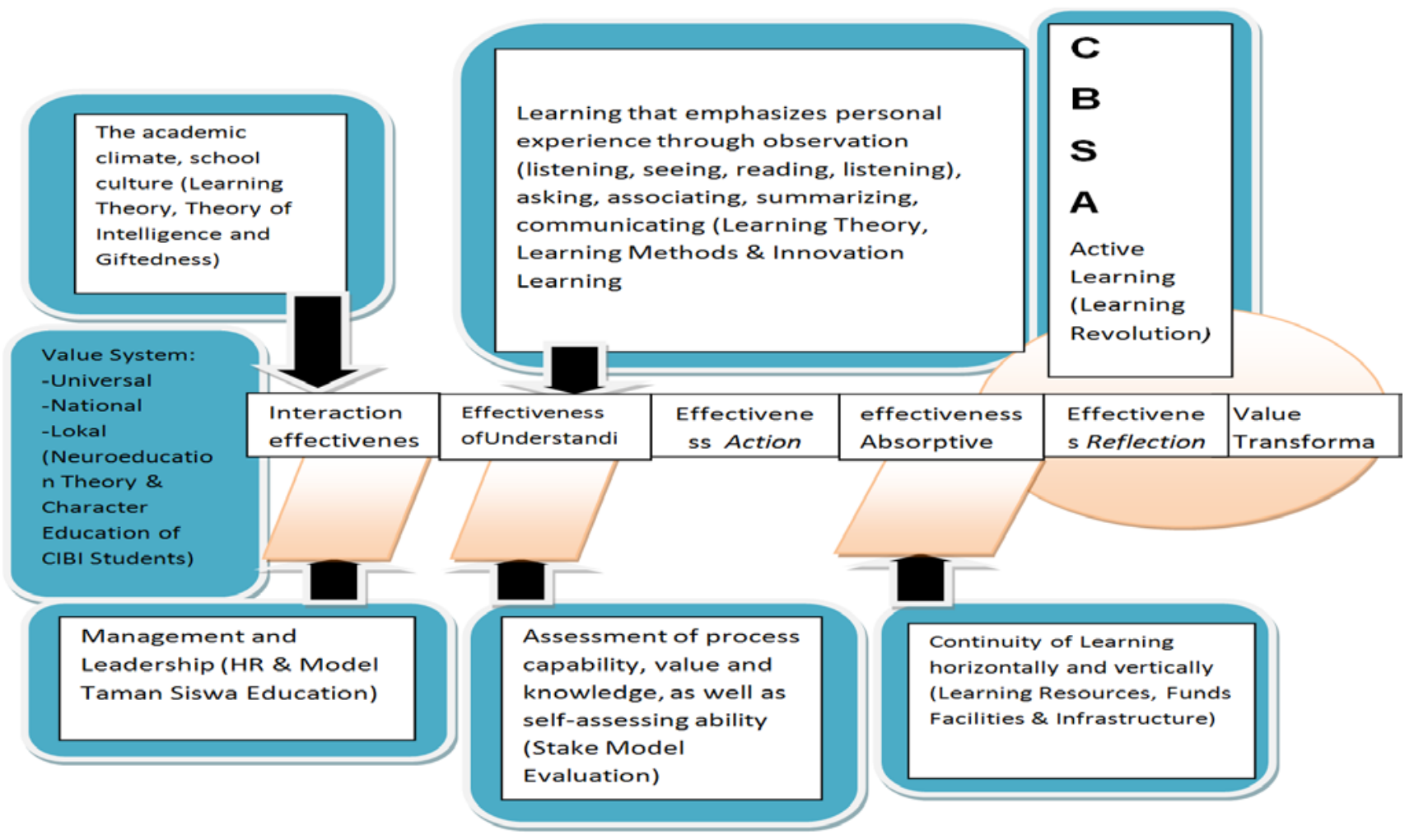

Figure 3. Integrative Thinking Framework - Holistic Implementation of the Accelerated Classroom Learning Program 
Based on the background of problem and identification / research focus, this research problem is formulated as follows: "how is the implementation of the accelerated educational program of smart students excel in SMA Unggulan X DKI Jakarta?" Specifically how are the implementation of inputs (antecedents), processes (transactions) and products (outcomes) accelerated educational programs special intelligent students in SMA Unggulan X DKI Jakarta? "

The results of the study are expected to be useful for: (1) providing feedback to stakeholders (teachers, students, principals, parents and all those who play a role in accelerated education) which is expected to be used to improve future programs. (2) to know the advantages and obstacles of the implementation of the accelerated education model, which can eventually be used as the basis for decision making on the improvement of acceleration education implementation process.

In addition, the results of the study are expected to be useful for other accelerated education education schools as a guide to further improve the effectiveness and excellence in management and learning and learning processes.

After the end of this study is expected to describe the implementation of the acceleration education model and the achievement of the acceleration education program objectives at the Unggulan X High School of DKI Jakarta Province.

\section{Research Methodology}

The study used a program evaluation method based on the Stake model. According to Stake model countenance as a model of qualitative evaluation (Stake in S. Hamid Hasan, [27]) Object evaluation is antecedents (inputs: students, teachers, curriculum, facilities and infrastructure, funds), transactions (process: curriculum implementation, And learning, teacher-student relationships, and evaluation systems used by teachers) and outcomes (product: students' smart intelligent absorption, intelligent student learning outcomes / criteria, intelligent special student adjustment, advanced study to exceptionally intelligent student universities, Residents of the school). This research tries to describe and describe phenomenon or relationship between phenomena studied in a systematic, factual and accurate within a certain time. And students in accelerated and regular classes are considered equivalent as objects in this study. Broadly speaking the implementation of the evaluation is shown in Figure 4 below.

The research object is a special intelligent student who is in the acceleration class in SMA Unggulan $X$ DKI Jakarta Province. The subjects of the study were determined by purposive, 1 headmaster, 1 deputy headmaster, 2 teachers of guardian of acceleration class, 2 regular homeroom teachers, 6 teachers of acceleration class study, 4 regular study subjects, 3 Teacher / BP, 10 classy intelligent students of class XI, 5 students of intelligent class $\mathrm{X}, 5$ regular students of class XII, 3 parents of special students, 2 school committees, and 4 administrative staff. Total 48 people.

This research is an evaluative research, using qualitative approach. In data collection, the instruments used are interview guides, documentation studies, observation guidelines and questionnaires. Testing of data validity is done by (1) credibility test, through observation, triangulation technique and source triangulation, member check, (2) Trasferability, by using evaluation result clearly, detailed, systematic, and reliable, (3) dependability, Through Audit of the entire process, and (4) confirmability, by tracing the origin of the data.

Primary and secondary data in the study were taken through observation, interview, questionnaire and document analysis. Prior to data retrieval, the instrument is validated first. Theoretical / construct validation is done by expert review, and / or panel. The process of theoretical study of a concept starts from the evaluation component, the evaluated aspect, the indicator to the translation and the writing of the instrument item. The researcher explains the expert who examines the instrument, the study procedure and the results of the study qualitatively. Furthermore, the researcher describes the procedure of qualitative / quantitative study and panel validation test.

While the Data Analysis Techniques collected from the results of the study were analyzed by descriptive method percentage, the analytical model used is interactive analysis model from Miles and Huberman with three main components are interrelated and can not be separated, namely data reduction, data presentation, and draw conclusions / verification; Then interpreted narratively as research findings. (Matthew B.Miles \& A. Michel Huberman, [45])

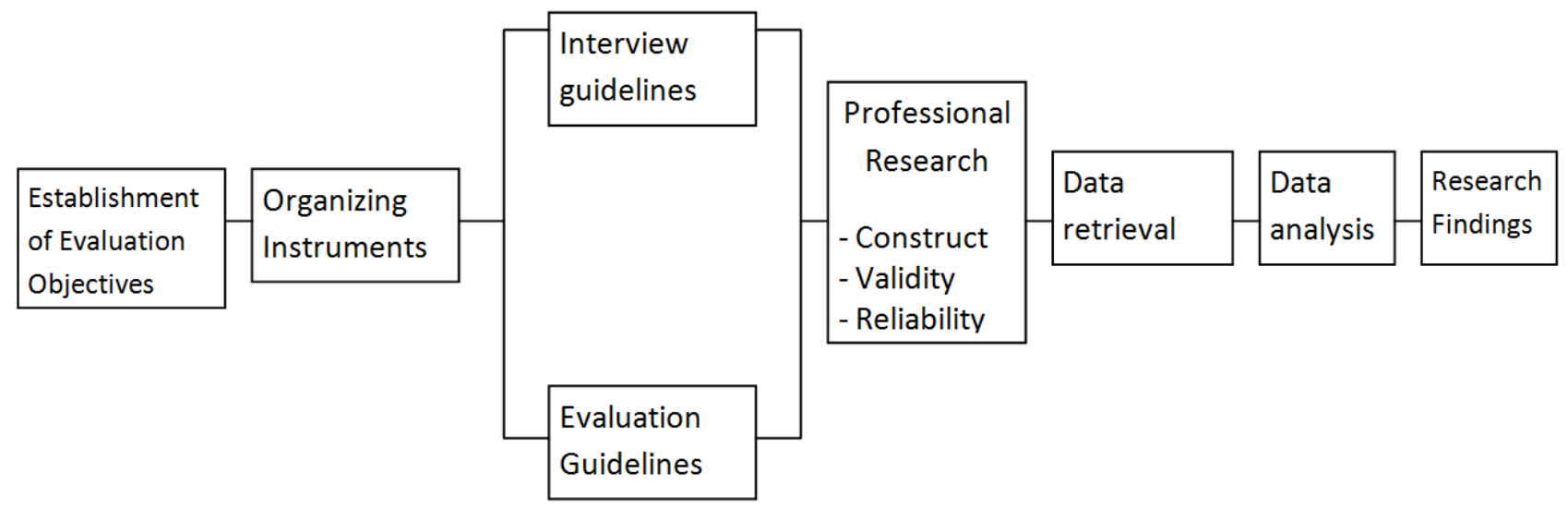

Figure 4. Evaluation Procedure 
The analytical model used is an interactive analysis model from Miles and Huberman ([45]), with three main components that are interrelated and inseparable, ie data reduction, data presentation, and conclusion / verification. Data of research result analyzed descriptively with program Nvivo 11, then present result of calculation in the form of percentage table.

\section{Results and Discussion}

\subsection{Research Results}

\subsubsection{Background Description}

The Special Capital City of Jakarta has five municipalities and one administrative district of the thousand islands. One of them is East Jakarta, which is located on the eastern side of Jakarta, a newly growing area close to the education centers, services and industrial centers of Pulo Gadung and Cakung. The existence of high school (Senior High School) Labschool as a place of research is located at Rawamangun Subdistrict, Kec.Pulo Gadung, into the East Jakarta City Region. SMA Labschool Rawamangun has seven grade (seven) classes each with two science courses and IPS, curriculum used is curriculum KTSP and curriculum 2013.Number of students per class of 38 students except acceleration class (15 and / 16 students Per class) .Status as a private school under the auspices of Pembina Foundation of the State University of Jakarta (UNJ). The number of teachers is 54 people, nonguru / administrative staff 4 people, 2 people laboratories, pramubakti (OB) 6 people. Number of class 20 classes (2 classes of acceleration) and Number of students in total approximately 720 students.

School Vision and Mission

Vision: Labschool is a school that prepares future leaders who are cautious, high integrity, strong fighting power, full personality, noble character, independent, and have high intellectual ability.

Mission:

1) Create a challenging learning environment, fun and meaningful

2) Conducting a humanistic and holistic inclusion learning process and have strong competitiveness

4) Make efforts to provide opportunities for educators Jalan Pemuda complex of Universitas Negeri Jakarta (UNJ)

3) Produce qualified graduates, have positive character,

and education personnel in order to have the initiative and independence in implementing creative and responsible learning.

5) Have educators and education personnel who set an example and perform their duties according to the purpose of the profession

6) Have a broad-minded leadership, oriented to the future and skilled in professional management

7) Establish partnerships with parents and communities in realizing Labschool's vision.

Evaluation standard criteria used are the theoretical standard of Stake evaluation model and objective standard criteria from the formal standard of accelerated program implementation from Directorate of Special Education Ministry of Education and Culture; Which will serve as the standard benchmark for measuring the level of achievement of accelerated education programs in schools. The standard criteria that will be used as a reference assessment has been presented in the previous chapter.

\subsubsection{Primary Data}

Based on observations, interviews, and document analysis, primary and secondary data were obtained. The following is the primary data:

1) SMA Labschool Rawamangun East Jakarta is headed by one principal and two Vice Principals of academic and student affairs. Have seven classes each level (21 Guardians, 31 teachers of study) each class 38 students (acceleration: 15 students) With 54 teachers, and three supervising teachers (BP / BK) and 4 administrative staff.

2) Schedule of Learning. This school only uses one shift, which is morning shift with teaching / learning activity from pkl.07.00 until at 15.30 WIB on Monday to Thursday, while Friday Fri, starting at 07.00 and finished at $11: 45 \mathrm{pm}$.

3) Student Acceleration Class. SMA Labschool Rawamangun East Jakarta has 30 special intelligent students who are in two classes (class X and Class XII) Number of male students: 8 students and 7 female students. Custom Intelligence based on IQ: 15 students, by Product: 5 students

\subsubsection{Secondary Data}

Secondary data in this research is a list of partner universities that accept graduate students of acceleration class. There are 11 students who can proceed to the top PTN.

\subsubsection{Research Findings}

Table 1. Theoretical Standard Criteria, Objective Standards, Programs Education Acceleration, Reality Results and Decisions

\begin{tabular}{|c|c|c|c|}
\hline $\begin{array}{l}\text { THEORETICAL } \\
\text { COMPONENTS/STANDARDS }\end{array}$ & OBJECTIVE STANDARDS & REALITY OF RESULT & DECISION \\
\hline INPUT (Antecedents) & $\begin{array}{l}\text { Program Strategy and Design: } \\
\text { 1. Student Objective Information } \\
\text { A. IQ Students above } 130 \text { (Very } \\
\text { Superior) } \\
\text { B. CQ Creativity Tests. Good } \\
\text { C. Task Commitment Task (TC) } \\
\text { D. Normal Exam Score Terms } \\
\text { Average } 8.0 \\
\text { E. Academic Ability Test (TPA) } \\
\text { Average Score Minimum } 8.0 \\
\text { F. Physical Health } \\
\text { G. Student Willingness and Parental } \\
\text { Agreement }\end{array}$ & $\begin{array}{l}\text { Based on the results of documentation } \\
\text { studies, self assessment, interviews, and } \\
\text { observations participate: } \\
\text { 1. Of all components of the student's } \\
\text { objective information } \\
\text { It meets the input criteria (Antecedents), } \\
\text { while the new IQ reaches ( } 40 \%) \text {. While } \\
\text { the subjective information component of } \\
\text { students all meet the standard (100\%) }\end{array}$ & $\begin{array}{l}\text { Input (Antecedents) } \\
\text { Average Category Very } \\
\text { Good (95.53\%) except on } \\
\text { the requirement of new IQ } \\
\text { reached ( } 40 \% \text { ) bad } \\
\text { category and Provision of } \\
\text { funds by society only } 60 \% \\
\text { good enough category }\end{array}$ \\
\hline
\end{tabular}




\begin{tabular}{|c|c|c|c|}
\hline & $\begin{array}{l}\text { Subjective Information } \\
\text { A. Self-nomination is available } \\
\text { B. Peer nomination available } \\
\text { C. Nominations by teachers are } \\
\text { available } \\
\text { D. Nominations by parents are } \\
\text { available } \\
\text { E. Socio-economic conditions of } \\
\text { parents support students }\end{array}$ & & \\
\hline & $\begin{array}{l}\text { 1. Teachers: administrative } \\
\text { requirements on the high category, } \\
\text { which include: } \\
\text { A. Minimal S1 in accordance with the } \\
\text { Field of Science Taught } \\
\text { B. Have Academic Qualification } \\
\text { Sufficient (Competence, Educator } \\
\text { Certificate) } \\
\text { C. Teaching Experience Minimum } 3 \\
\text { Years Good Achievement } \\
\text { D. Prepared to Teach in Class of } \\
\text { Intelligent / Aksel Special Students }\end{array}$ & $\begin{array}{l}\text { Based on the results of documentation } \\
\text { studies, self assessment, interviews, and } \\
\text { observations participate: } \\
\text { 2. The administrative requirements of } \\
\text { teachers in the high category: } \\
\text { A. S1 education in accordance with the } \\
\text { field of science that is taught } \\
\text { B. Have sufficient academic qualifications } \\
\text { (competence, educator certificate) } \\
\text { approximately (72\%) } \\
\text { C. Learning experience at least } 3 \text { years of } \\
\text { good achievement } \\
\text { D. Prepared to teach in class of special } \\
\text { intelligent students / akse (28\%) Total } \\
\text { (100\%) }\end{array}$ & \\
\hline & $\begin{array}{l}\text { 1. Curriculum } \\
\text { Highly Differentiated Accelerated } \\
\text { Education Curriculum }\end{array}$ & $\begin{array}{l}\text { Based on the results of documentation } \\
\text { studies and interviews: } \\
\text { 3. Modify from curriculum KTSP with } \\
40 \% \text { face-to-face and } 60 \% \text { independent } \\
\text { (active student learning / ASL) (100\%) }\end{array}$ & \\
\hline & $\begin{array}{l}\text { 1. Facilities (Books and Learning } \\
\text { Materials) and educational } \\
\text { infrastructure acceleration at least } \\
90 \% \text { adequate }\end{array}$ & $\begin{array}{l}\text { Based on the results of documentation } \\
\text { studies and interviews: } \\
\text { 4. Sarana (Books and learning materials) } \\
\text { and infrastructure: Very adequate and } \\
\text { conducive to carrying out learning } \\
\text { activities and other academic and non } \\
\text { academic activities (extra curricular and } \\
\text { kokurikuler) is very complete }(95 \%) \text { ) }\end{array}$ & \\
\hline & $\begin{array}{l}\text { 1. Funds / Financing: } \\
\text { Accelerated Education Fund: } \\
\text { Sufficient Financing for Operational } \\
\text { and Quality Improvement of } \\
\text { Acceleration Program }\end{array}$ & $\begin{array}{l}\text { Based on interview results: } \\
\text { 5.Dana / Financing: sufficient and } \\
\text { adequate for operational financing and } \\
\text { quality improvement of acceleration } \\
\text { program (60\%) Total less ( } 40 \%) \text { from } \\
\text { Yayasan Pembina UNJ or other legitimate } \\
\text { sources }\end{array}$ & \\
\hline & $\begin{array}{l}\text { 1. Academic Calendar: achievement } \\
\text { of effectiveness in high category }\end{array}$ & $\begin{array}{l}\text { Based on the results of documentation } \\
\text { studies and observations: Effectiveness: as } \\
\text { planned and appropriate Time and } \\
\text { objectives in the implementation (100\%) }\end{array}$ & \\
\hline \multirow[t]{6}{*}{ PROSES (Transaction) } & $\begin{array}{l}\text { 1. Teacher Profile acceleration in high } \\
\text { category }\end{array}$ & $\begin{array}{l}\text { Based on the results of open } \\
\text { questionnaires to students about students } \\
\text { 'perceptions of teachers' profiles are very } \\
\text { good }(100 \%)\end{array}$ & $\begin{array}{l}\text { Process (Transaction) } \\
\text { Average: (100\%) Very } \\
\text { good category, except for } \\
\text { teacher interest in } \\
\text { accelerated classes (50\%) } \\
\text { bad category and } \\
\text { evaluation system used } \\
\text { new (90\%) category good } \\
\text { enough. }\end{array}$ \\
\hline & $\begin{array}{l}\text { 2. Teacher Competence } \\
\text { Acceleration in high category }\end{array}$ & $\begin{array}{l}\text { Based on the results of open } \\
\text { questionnaires to students about students } \\
\text { 'perceptions of teachers' competence aksel } \\
\text { students think Good }(90 \%)\end{array}$ & \\
\hline & $\begin{array}{l}\text { 3. Teacher Interests Teach the } \\
\text { acceleration classes in high category }\end{array}$ & $\begin{array}{l}\text { Based on the results of open } \\
\text { questionnaires to students about students' } \\
\text { perceptions of the terms and interests of } \\
\text { teachers teaching in the classroom, } \\
\text { students argue (50\%) }\end{array}$ & \\
\hline & $\begin{array}{l}\text { 4. Implementation of Learning } \\
\text { Curriculum: } \\
\text { On High Categories }\end{array}$ & $\begin{array}{l}\text { Based on the results of interviews and } \\
\text { observations of Learning Curriculum } \\
\text { Implementation in High Categories } \\
(100 \%)\end{array}$ & \\
\hline & $\begin{array}{l}\text { 5. Implementation of Learning and } \\
\text { Learning Activities on High } \\
\text { Categories }\end{array}$ & $\begin{array}{l}\text { Based on interviews and observations of } \\
\text { Learning and Learning Activities at High } \\
\text { Categories (100\%) }\end{array}$ & \\
\hline & $\begin{array}{l}\text { 6. How Teachers Foster Interpersonal } \\
\text { Relationships with Students in } \\
\text { Acceleration Class at High Categories }\end{array}$ & $\begin{array}{l}\text { Based on interviews and observations } \\
\text { How Teachers Build Interpersonal } \\
\text { Relationships with Students in } \\
\text { Acceleration Class at High Categories } \\
(74 \%)\end{array}$ & \\
\hline
\end{tabular}




\begin{tabular}{|c|c|c|c|}
\hline & $\begin{array}{l}\text { 7. Sociometry / social relations } \\
\text { structure of Aksel Students in high } \\
\text { category }\end{array}$ & $\begin{array}{l}\text { Based on self assessment through Student } \\
\text { Sosiometri Akseler (100\%) }\end{array}$ & \\
\hline & $\begin{array}{l}\text { 8. Extracurricular Student Activity } \\
\text { Acceleration in high category }\end{array}$ & $\begin{array}{l}\text { Based on interviews and self assessment } \\
\text { Extracurricular Activities of Aksel } \\
\text { Students (100\%) }\end{array}$ & \\
\hline \multirow[t]{2}{*}{$\begin{array}{l}\text { COMPONENT/THEORETICAL } \\
\text { STANDARDS }\end{array}$} & OBJECTIVE STANDARDS & REALITY OF RESULT & DECISION \\
\hline & $\begin{array}{l}\text { 9. Evaluation System Used by } \\
\text { Teachers in Learning and Learning } \\
\text { Process in Acceleration Class in High } \\
\text { Categories }\end{array}$ & $\begin{array}{l}\text { Based on interviews and classroom } \\
\text { observation } \\
\text { Evaluation System Used by Teachers in } \\
\text { Learning and Learning Process in } \\
\text { Acceleration Class in High Categories } \\
(90 \%)\end{array}$ & \\
\hline \multirow[t]{3}{*}{ PRODUCT (Outcomes) } & $\begin{array}{l}\text { 1. National Examination Results } \\
\text { (UN): } \\
\text { Absorption Power of Special } \\
\text { Intelligent Students While in the } \\
\text { Acceleration Class at High Categories } \\
\text { (UN Minimum Class of 8.0) }\end{array}$ & $\begin{array}{l}\text { Based on documentary study: Capacity of } \\
\text { Smart Students Absorption During } \\
\text { Acceleration Class at High Categories } \\
\text { (UN Minimum Class of } 8.0)(70 \%)\end{array}$ & $\begin{array}{l}\text { PRODUCT (Outcomes) } \\
\text { Average: (100\%) Very } \\
\text { good category, except on } \\
\text { the average UN ( } 70 \%) \text { in } \\
\text { the Good category } \\
\text { acceleration category. }\end{array}$ \\
\hline & $\begin{array}{l}\text { 2. Learning outcomes: } \\
\text { Learning Outcomes / Criteria for } \\
\text { Special Smart Students While in the } \\
\text { Acceleration Class on High } \\
\text { Categories }\end{array}$ & $\begin{array}{l}\text { Based on documentation study } \\
\text { Learning Outcomes / Criteria for Special } \\
\text { Smart Students While in the Acceleration } \\
\text { Class at High Categories (100\%) }\end{array}$ & \\
\hline & $\begin{array}{l}\text { 3. Adjustment (Comprehensive \& } \\
\text { Competitive Intelligence): } \\
\text { Adjustment of Smart Intellectual } \\
\text { Students After Passing Minimum } \\
\text { Equals Regular Class } \\
\end{array}$ & $\begin{array}{l}\text { Based on self-assessment Personal } \\
\text { Adjustment (comprehensive and } \\
\text { competitive intelligence) Special Smart } \\
\text { Student After Graduation Minimum } \\
\text { Equals Regular Class (100\%) } \\
\end{array}$ & \\
\hline \multirow[t]{4}{*}{$\begin{array}{l}\text { COMPONENT/THEORETICAL } \\
\text { STANDARDS }\end{array}$} & OBJECTIVE STANDARDS & REALITY OF RESULT & DECISION \\
\hline & $\begin{array}{l}\text { 4. Special Smart Student Behavior } \\
\text { possesses (Characters Basic Values) } \\
\text { High category }\end{array}$ & $\begin{array}{l}\text { Based on self-assessment Behavior of } \\
\text { Smart Students having (Characters Basic } \\
\text { Values) High category (100\%) }\end{array}$ & \\
\hline & $\begin{array}{l}\text { 5. Uptake of Excellence PTN } \\
\text { Smart Special Students can Forward } \\
\text { to PTN (absorption to PTN Featured } \\
\text { Minimal 90\% }\end{array}$ & $\begin{array}{l}\text { Based on the results of interviews and } \\
\text { study documentation of Smart Students } \\
\text { Can Continue to PTN (absorption to PTN } \\
\text { Minimum } 90 \%(90.90 \%)\end{array}$ & \\
\hline & $\begin{array}{l}\text { 6. Community Participation / School } \\
\text { Committee: } \\
\text { School Residents' Opinion on the } \\
\text { Acceleration of Acceleration in High } \\
\text { Categories }\end{array}$ & $\begin{array}{l}\text { Based on the results of interviews on } \\
\text { participation of school committees / } \\
\text { committees: School Residents' Opinion of } \\
\text { Acceleration in High Categories (91\%) }\end{array}$ & \\
\hline
\end{tabular}

\subsection{Discussion of Research Results}

Based on the exposure of the research data above, that the school that opened the acceleration class has been accepted by the community well. Especially those who have gifted children are intelligently special. However, the proportion of exceptional intelligent students served in the school is still very limited ie 30 students for two classes.

While the government policy for the development of accelerated education program is continuously improved, so that the pattern of smart gifted students can be served optimally in every unit of school / classroom activity that opens the acceleration class program. Thus, with the service model, gifted children of exceptional intelligence can obtain their rights according to their potential and are protected by national education system law proportionally and equitably.

The accelerated education program was originally a government project and was only conducted in government schools and private schools designated by the government as a model to serve gifted, intelligent, and highly exclusive gifted children, but in its development could serve all students from all communities whose children Has a special intelligent ability through the selection set by the accelerated class service delivery school. Information and socialization of accelerated education programs is needed both directly and in print and electronic media so that people in general know and recognize all accelerated education program services before they decide to send a special intelligent child in school / acceleration. With evaluation framework and monotoring Program of Giftedness (acceleration) that plot as depicted in groove chart Figure 5 below.

From the results of the overall evaluation of the components of the implementation of the accelerated education program for the input component (antecedents) obtained an average percentage of (95.53\%) with very good category; Except for the IQ requirement of exceptional smart students at the time of admission of new acceleration program (40\%) is still below the standard that should be (90\%); And on the components of the provision of funds by the community to improve the quality of accelerated education programs that only have the contribution (60\%) good enough category (not enough), which should be (90\%).

While the result of evaluation on the component of the process (transactions) the effectiveness of the acceleration program implementation obtained an average percentage (100\%) with the category of assessment is very good; Except in the interest of teachers teaching in accelerated classes (50\%) bad category, should (90\%) category very well; And the evaluation system used by new acceleration teachers $(90 \%)$ is very good category (should be $90 \%$ very good category). 


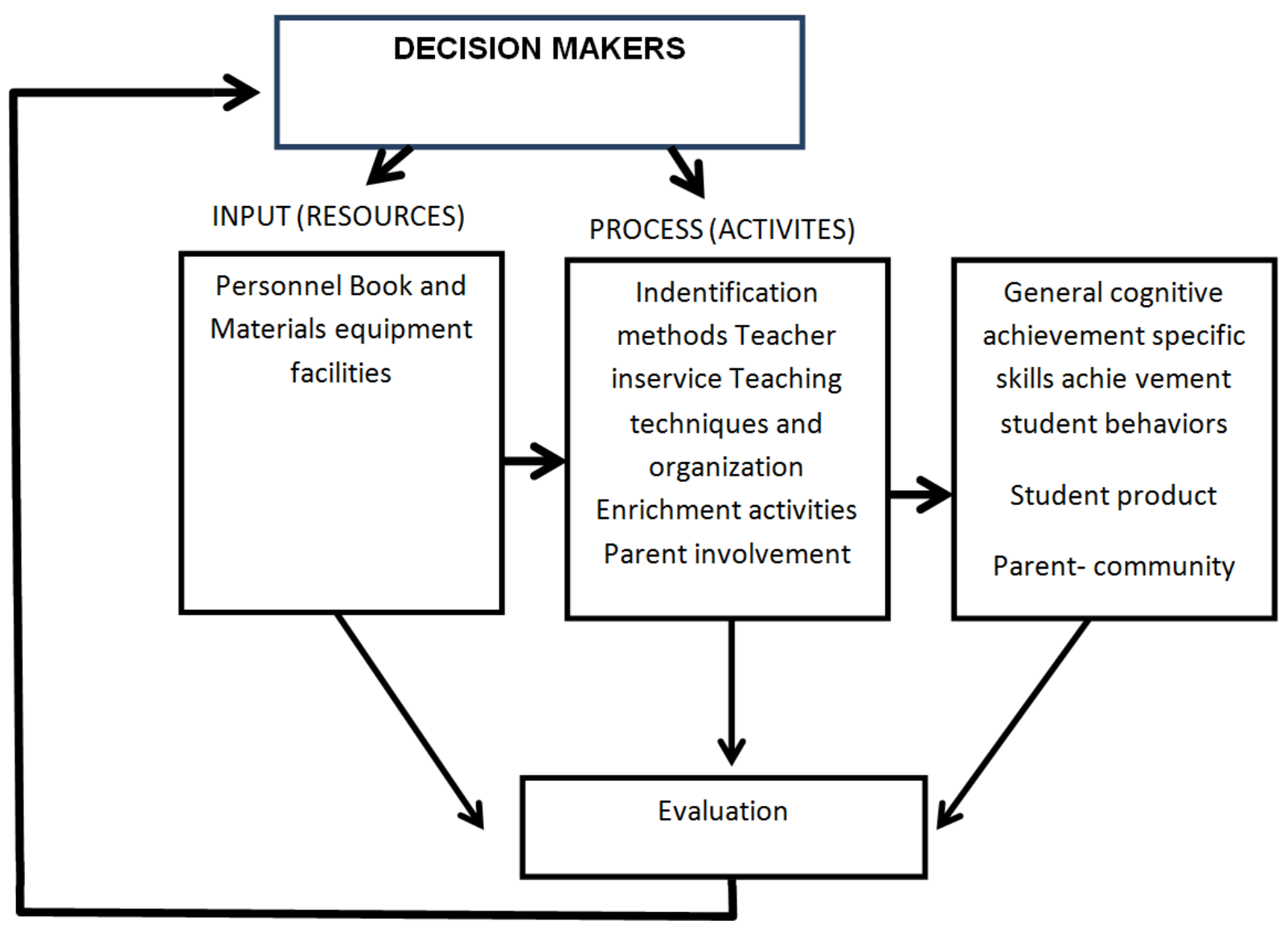

Figure 5. Framework for the Evaluation and Monitoring of a Gifted Program (Gary A. Davis, Sylvia B.Rimm, Del Siegle, [9])

Furthermore, product evaluation (outcomes) shows that the average percentage of excellent students in the acceleration class reaches (100\%) very good category, except on the achievement of UN value still not reached the standard that is (70\%) category Well, still under the category of excellent satandar (90\%).

From the description of the above results it can be concluded that all components have been running properly; Although among the components such as students who will follow the accelerated program based on IQ is not standard, also the cost / funding from the community is not sufficient to improve the quality of the acceleration program, on the one hand. On the other hand, teachers' interest and evaluation system must be improved so that the learning process in the acceleration class is more successful maximally (very good category). It is characterized by the product in which the accelerated students of the National Exam results (UN) just reached (70\%) good category. This means it is still below (the standard should be high / very good: 90\%).

\section{Conclusions and Recommendations}

Based on the results of the above explanation, from the results of the findings analysis, it can be concluded that the accelerated educational program of special intelligent students in SMA Unggulan X DKI Jakarta has been done according to policy. And the finding of school-based acceleration education model / IQ (school based giftedness) and performance / gift-oriented (performance based giftedness). Although there is still an ongoing process it needs refinement. Because of the qualitative nature of research it is necessary to earnest effort in obtaining data from the field of research so that the results are more meaningful as a research findings to enrich the repertoire of education science especially education technology, the results below will be maximal, namely:

First, the input / atecedents: the result of the average category is very good (95,53\%), except on the requirement of student IQ when entering into student of acceleration (40\%) is good enough, and public funding (60\%) less good category. Therefore it is necessary to: (a) be done at the beginning of student enrollment into accelerated student, (b) be screened and screened by skilled people. (C) Individual Learning Program (PPI) in high-quality because of the proportion of $40 \%$ face to face, $60 \%$ independent learning tasks. (D) realistic fund raising/costs to improve the quality of the accelerated program.

Second, Process / transactions: the average yield (100\%) category is very good. Except for teachers' interest in accelerated teaching (50\%) bad category and assessment system used by teacher in acceleration class (90\%) category good enough. Therefore, it is necessary to: (a) the teacher training before teaching in the acceleration class and the training of the acceleration assessment system (b) the learning and learning activities should pay attention to the entry behaviors according to their talents and interests, as well as their ability in learning and learning process, Here is still common / classical (the approach of school based gfttedness, such as IQ) is more pronounced, when compared to a creative-oriented, 
product-oriented (creative-based) oriented approach that benefits the many and tangible communities.

Third, the product / outcomes: the average yield (100\%) category is very good, except on the average result of the UN (70\%) Good category, (still below the standards that should be $90 \%$, high / excellent category) . It is therefore necessary to: (a) Efforts to develop the potential of sophisticated students in a sustainable manner, (b) Especially in the aspect of intellectual development: academic, social and emotional, spiritual, kinesthetic, competitive in learning process by applying innovative learning model joyful learning / PAKEM And other learning innovations that can be done by teachers and supported by adequate facilities and infrastructure, facilitate and involvement of related parties in realizing the process and learning outcomes of intelligent students special power and meaningful for their life.

Based on the above conclusions, the recommendation / suggestion that the acceleration education program needs to be continued and improved its quality starting from the planning, the process and its implementation by considering the following matters:

First, there needs to be a selection pattern that can capture and screen prospective students of acceleration early so that they are better prepared and matured academically, socially, psychologically and spiritually in following the learning in the acceleration class. Kurtilas (Curriculum 2013) should accommodate the needs of the accelerated students rather than eliminate them by integrating in regular classes / inclusions that would obscure the essence of the results of this study, which is in line with the Law and the constitution of the Unitary Republic of Indonesia so that students will be given special services in learning and learning according to potential And needs. Individuals qualified according to the talent potential and uniqueness of students is needed. Third, the students' actual (entry behavior) ability and variety must be the teacher's footsteps in providing quality acceleration learning service and meaningful. Fourth, the interaction between teachers and students in order to establish interpersonal relationships in the learning activities should continue to be improved in relation to the development of intelligence: spiritual, emotional and social, intellectual, kinesthetic and competitive (comprehensive and competitive intelligence) and the basic values of character / character Sublime as it is taught in Taman Siswa schools for the special intelligent students. So that special intelligent students are able to act Think globally act locally (think global, act locally). Fifth, Facilities and infrastructure are very adequate to continuously improved the quantity and quality in providing ease of learning and accelerated learning services on the special intelligent students so that the potentials that have developed and realized optimally and even maximal. Sixth, the amount of funds needed to improve the quality of accelerated education programs should be realistically aligned to the number and needs of schools and the state of special intelligent students so that their use will be very effective-efficient. Seventh, Implementation of evaluation should be done continuously and continuously, so that the result of decision given by teacher to its student is accurate, accurate and reliable. Enrichment of essential material is perfect for spurring their potential to grow better. Eighth, the same vision and mission by all school citizens who are involved and have the same interests about accelerated education for his special intelligent son, which is still very much needed by the community. And Ninth, prior to the implementation of a model, a continuous policy study and preliminary studies and studies will be conducted to determine the effectiveness of an implementation of the policy.Second, learning plans for special smart student is special because it is designing learning programs

Individuals qualified according to the talent potential and uniqueness of students is needed. Third, the students' actual (entry behavior) ability and variety must be the teacher's footsteps in providing quality acceleration learning service and meaningful. Fourth, the interaction between teachers and students in order to establish interpersonal relationships in the learning activities should continue to be improved in relation to the development of intelligence: spiritual, emotional and social, intellectual, kinesthetic and competitive (comprehensive and competitive intelligence) and the basic values of character / character Sublime as it is taught in Taman Siswa schools for the special intelligent students. So that special intelligent students are able to act Think globally act locally (think global, act locally). Fifth, Facilities and infrastructure are very adequate to continuously improved the quantity and quality in providing ease of learning and accelerated learning services on the special intelligent students so that the potentials that have developed and realized optimally and even maximal. Sixth, the amount of funds needed to improve the quality of accelerated education programs should be realistically aligned to the number and needs of schools and the state of special intelligent students so that their use will be very effective-efficient. Seventh, Implementation of evaluation should be done continuously and continuously, so that the result of decision given by teacher to its student is accurate, accurate and reliable. Enrichment of essential material is perfect for spurring their potential to grow better. Eighth, the same vision and mission by all school citizens who are involved and have the same interests about accelerated education for his special intelligent son, which is still very much needed by the community. And Ninth, prior to the implementation of a model, a continuous policy study and preliminary studies and studies will be conducted to determine the effectiveness of an implementation of the policy.

\section{References}

[1] Amstrong, Thomas. Multiple Inteligences, in the Classroom, 3rd Edition, Alexandria-Virginia USA: ASCD Member Books, 2009.

[2] "Intelligent Children Ignored (in Humanities)". Kompas, February 2, 2009.

[3] "Smart Children Tend To Be Naughty If Less Attention (in Science \& Health)" Republika, February 9, 2009.

[4] National Education Standards Agency, Regulation of the Minister of National Education Republic of Indonesia Number 41 Year 2007 Concerning Process Standards for Basic and Secondary Education Units, Jakarta: 2007.

[5] Bandur, Agustinus, Qualitative Research: Methodology, Design, \& Data Analysis Techniques with NVIVO 10, Jakarta: Media Discourse Partners, 2014.

[6] Thesis Writing and Dissertation Handbook, Jakarta: Graduate Program Jakarta State University, 2012. 
[7] Colangelo, Nicholas and Davis, A. Gary (Eds.) Handbook of Gifted Education, Boston: Allyn \& Bacon, 1991.

[8] Davis, Gary A, Gifted Child and Gifted Education (A Handbook for Teachers and Parents), Translator: Ati Cahyani, Jakarta: PT. Index, 2012.

[9] Davis, Gary A, Rimm, SB, Siegle, D., Education of The Gifted and Talented, 6th Edition, Upper Saddle River - New Jersey : Pearson Education Inc., 2011.

[10] Depdikbud, School Development Plus, Jakarta: Depdikbud RI, 1994.

[11] Depdiknas. Penatalaksanaan Psychology Acceleration Program. Jakarta: Directorate General of MPDM-DPSLB, 2007 (1a).

[12] Depdiknas. Jakarta: Directorate General of MPDM-DPSLB, 2007 (1b).

[13] De Souza, Marian, et.al. (Eds.), International Handbook of the Religious, Moral and Spiritual Dimensions in Education, International Handbook of Religion and Education 1, section 1 \& 2, Dordrecht - The Netherlands: Springer Science + Bussiness Media BV, 2009.

[14] De Souza, Marian, et.al. (Eds.), International Handbook of the Religious, Moral and Spiritual Dimensions in Education, International Handbook of Religion and Education 1, section 3. 4, \& 5, Dordrecht - The Netherlands: Springer Science + Bussiness Media BV, 2009.

[15] Dewantara, Ki Hajar, Education, Part One, Yogyakarta: Mejelis Luhur Persatuan Taman Siswa, 2004.

[16] Directorate of Special Education, Learning Speed Program (Acceleration), Basic and Secondary Education (http://www.ditplb.or.id/profile.php?id=60), (accessed: 7 Septemb er 2007).

[17] Fitzpatrick,Jody., Sanders, James R.,\& Worthen, Blaine R, Program Evaluation, Alternatif Approaches and Practical Guidelines, Boston : Pearson Education Inc, 2004.

[18] Fosnot, Twomney, C. Constructivism Theory, Perspective and Practice, New York: Teachers College, 1996.

[19] Friedman, Thomas L., The World Is Flat, Sejarah Ringkas Abad Ke-21, Alih Bahasa : P.Buntaran dkk., Jakarta : PT. Dian Rakyat, 2006.

[20] Gardner, Howard, Intelligences Reframed, Multiple Intelligence for the 21st Century, New York : Basic Book, A Member of the Persens Books Group, 1999.

[21] Gardner, Multiple Intelligences (Kecerdasan Majemuk Teori dalam Praktek, alih bahasa:Alexander Sindoro, Batam Centre Interaksara, 2003.

[22] Gifted Review, Jurnal Keberbakatan Dan Kreativitas, Depok: Fakultas Psikologi UI, 2008.

[23] Google. Robert E. Stake Director Center for Instructional Research and Curriculum Evaluation (CIRCE). 2002 (http://www.ed.uiuc.edu/circe/Robert_Stake html) (diakses 17 Juli 2010).

[24] Google. Robert E.. Neuroeducation (http://www.dana.org/news/publications.aspx?id=23946) (diakses 8 Maret 2012).

[25] Gredler. M. E.Learning and Instruction: Theory into Practise Sixth Edition, Upper Saddle River - New Jersey : Pearson Education Inc., 2009.

[26] Hardiman, Mariale; Magsamen, Susan; Khann, Guy Mc., Neuroeducation : Learning, Arts, and The Brain, finding and challenges for educator and Researches from 2009 John Hopkin University Summit, New York/Washington DC: Dana Press, 2009 (www.dana.org/ news/publication.aspa?id) (diakses 8 Maret 2012).

[27] Hasan, S. Hamid, Evaluasi Kurikulum, Bandung: Sekolah Pascasarjana UPI-PT. Remaja Rosdakarya, 2008.

[28] Hawadi, Lydia Freyani, "Identifikasi Anak Berbakat Intelektual menurut Konsep Renzulli Berdasarkan Nominasi Guru, Teman Sebaya, dan Diri Sendiri.” Disertasi, Universitas Indonesia, 1993.

[29] Hawadi, Reni Akbar, Identifikasi Keberbakatan Intelektual Melalui Metode Non-Tes Dengan Pendekatan Konsep Keberbakatan Renzulli, Jakarta : PT.Grasindo, 2002.

[30] Hawadi, Reni Akbar, (Ed.). Akselerasi, A-Z Informasi Program Percepatan Belajar dan Anak Berbakat Intelektual, Jakarta: PT.Grasindo, 2004.

[31] Hergenhahn,B.R. \& Olson, Matthew H., An Introduction to Theories of Learning,Fourth Edition, Englewood Cliffs, New Jersey : Prentice Hall International Inc., 1993.
[32] Herpatiwi, "Implementasi Pendidikan Inklusi di Sekolah Dasar X Provinsi Lampung”. Disertasi, Universitas Negeri Jakarta, 2007.

[33] Herwanto, "Peranan Lingkungan Pendidikan Terhadap Motif Berprestasi dan Keyakinan Spiritual (Penelitian di Kalangan Siswa Berbakat Memimpin SMU Unggulan - Non Unggulan DKI Jakarta”. Tesis, Universitas Indonesia, 2003.

[34] Herwanto, Membangun Manusia Unggul Melalui Pendidikan Karakter Berbasis Pengenalan Jati Diri Perspektif Psikosipiritual (Sebuah Tantangan Pendidikan Indonesia Dalam Membangun Generasi Emas), dalam Tantangan Pendidikan Indonesia dalam Membangun Generasi Emas-Bunga Rampai 50 Tahun UNJ, (Nadiroh, dkk.,eds.), Jakarta : Program Pascasarjana Universitas Negeri Jakarta, 2014.

[35] Hill, Winfred F., Theories Of Learning, (Theories of Learning, Conception, Comparison, and Significance, Translator: M.Khozim, Bandung: Nusa Media, 2009.

[36] Idris, Asmaniar Z., "Acceleration and Escalation Program: An Evaluative Research at SLTP X Jakarta". Dissertation, Jakarta State University, 2005.

[37] Idris, Asmaniar Z., "Acceleration and Escalation Program: An Evaluative Research at SLTP X Jakarta, in Science Journal of Parameter, Jakarta: Jakarta State University No.21, XXII Year, January, 2005.

[38] Idris, Asmaniar Z., "Acceleration and Escalation Program: An Evaluative Research at JSS X Jakarta, in Journal of Education Technology (Jakarta: Prodi Teknologi Pendidikan Pascasarjana UNJ, Vol.6 No.2, August, 2004.

[39] Jarvis, Matt, Psychology Theories, Modern Approaches to Understanding Behavior, Feelings \& Human Thoughts), Translators: SPA-Teamwork, Bandung: Nusa Media, 2009.

[40] Kemdiknas, Psychological Management Guidelines for Special Education Services For Special Intelligent Educate Participants, Jakarta: DirjenMPDM-DirPSLB, 2010 (1a).

[41] Kemdiknas, Teachers and Parents Guide Special Intelligent Education, Jakarta: DirjenMPDM-DirPSLB, 2010 (1c).

[42] Khatena, Joe, Gifted, challenge And Response For Education, Itasca, Illinois-USA: F.E.Peacock Publishers, Inc., 1992.

[43] MacGilchrist, Barbara; Myers, Kate; Reed, Jane, The Intelligent School, Second Edition, London: SAGE Publications Ltd., 2006.

[44] Meier, Dave, The Accelerated Learning Hanbook (Creative \& Effective Guide Designing Education And Training Program), Translator: Rahmani Astuti, Bandung: Kaifa Publisher, 2002.

[45] Miles, Matthew B., \& Huberman, A.Michel, Qualitative Data Analysis, Source Books About New Methods, Jakarta: UI PRESS, 1992.

[46] Moleong, J. Lexy. Qualitative Research Methodology, Revised Edition. Bandurg: PT Remaja Rosdakarya, 2007.

[47] Morgan, Clifford T., Introduction to Psychology, 7th Edition, New York: McGraw - Hill Book Co., 1986.

[48] Munandar, Utami and Semiawan, Conny (Eds.), Optimizing Excellence In Human Resource Development, Proceeding of the Fourth Asia-Pacific Conference on Giftedness Jakarta, 4-8 August 1996, Jakarta: UI Press, 1996.

[49] Munandar, Creativity and Giftedness, Strategy to Achieve Creative \& Talent Potential, Jakarta: PT.Gramedia Pustaka Utama, 1999.

[50] Musnir, Diana Nomida, Hand Out Learning, Jakarta: Prodi Educational Technology (S3), UNJ, Without Year Neuroeducation, New Orientation in Science Education (in Education \& Culture), Kompas, 5 April 2011.

[51] Nulhakim, T.Rusman, "Evaluation of Acceleration Program, An Evaluative Study of CIPP Model Concerning Acceleration Program At A High School in DKI Jakarta". Dissertation, State University of Jakarta, 2006.

[52] "Intelligent People (in Headlines)". Republika, December 21, 2010

[53] Owen, John M. Program Evaluation Forms and Approaches. Australia: Southwood Press Pty Limited, 1993.

[54] Parkay, Forrest W; Stanford, Beverly Hardcastle, Becoming a Master, Translator: Dani Dharyani, Jakarta: Index, 2008.

[55] Patton, Michael Quinn, Qualitative Evaluation Method, Translator: Budi Puspo Priyadi, mold II, Yogyakarta: Student Literature, 2009

[56] Piaget, Jean \& Inhelder, Barbel.The Psychology of The Child (Child Psychology), Magnum Opus, Translator: Miftahul Jannah, Yogyakarta: Pustaka Pelajar, 2010.

[57] Popham. W. James, Educational Evaluation. New Jersey: PrenticeHall Englewood Cliffs, 1975. 
[58] "The Potential of Gifted Children Minimally Attention (in Education \& Culture)". Kompas, February 24, 2010.

[59] Prasedyawati, Arniati; Munandar, Utami; And Bonang, Engelina, "The relationship between self-regulation in learning, self-efficacy, home learning environment, and intelligence with learning achievement (A comparative study of gifted students with regular high school students in Jakarta)". In Gifted Review - Journal of Giftedness and Creativity, Faculty of Psychology UI Depok, Vol.03.No.01, February 2009.

[60] Renstra Depdiknas 2000-2009, National Education Development, Jakarta: 2009.

[61] Rose, Colin \& Nicholl, Malcolm J., Accelerated Learning For The 21st Century (Translator: Dedy Ahimsa, Bandung: Nuansa, 2002.

[62] Sallis, Edward, Total Quality Management In Education, Interpreting: Ahmad Ali Riyadi and Fahrurrozi, Print V, Yogyakarta: IRCiSoD, 2007.

[63] Sedyawati, Edi, et al., Guidance of Manpower of Luhur, Luhur, Jakarta: Balai Pustaka, 1997.

[64] Grasindo, 1997.

[65] Grasindo, Higher Education: Increasing Human Ability as Long as Life is Possible. Jakarta: PT Grasindo, 1999.

[66] Grasindo, Learning and Learning in Early Childhood (Preschool and Primary School). Jakarta: PT Prenhallindo, 2002.

[67] Grasindo, Family Education In The Global Era. Jakarta: PT Prenhallindo, 2002

[68] Grasindo, and Mangunsong, Frieda, Twice Exceptionality, Exploring, Knowing, Identifying, and Maintaining , Jakarta: Kencana, 2010.

[69] Grasindo, Et.al., Creativity Giftedness, Why, What, and How, Jakarta: PT.Index, 2010.

[70] Grasindo, Interview Results on May 3, 2013, Jakarta, PPS UNJ.

[71] Slavin, Robert E., Educational Psychology, Theory and Practice, Eighth Edition, Volume 1 Translator: Marianto Samosir, Jakarta: Index, 2008.

[72] Grasindo,Educational Psychology, Theory and Practice, Eighth Edition, Volume 2 Translator: Marianto Samosir, Jakarta: Index, 2008.
[73] Smith, Mark K.et al. Learning \& Teaching Theory, Translator: Abdul Qadir Shaleh, Yogyakarta: Mirza Media Pustaka, 2009.

[74] Sousa, David A., How The Gifted Brain Learns, Thousand OaksCalifornia: Corwin Prerrs, Inc.-A Sage Publications Company, 2003.

[75] Snelbecker, Glenn E., Learning Theory, Instructional Theory, and Psychoeducational Design, New York: McGraw-Hill Book Company, 1974.

[76] Stake, Robert E., The Countenance of Educational Evaluation, CIRCE (Center for Instructional Research and Curriculum Evaluation), College of Education University of Illinois at UrbanaChampaign, (http://education.illinois.edu/CIRCE/) (accessible July 17, 2010).

[77] Teacher Education Science FIP Team UPI, Science \& Education Application, Part 1 Theoretical Education Science, Jakarta: Grasindo-PT.Imperial Bhakti Utama, 2007.

[78] Law Number 20 Year 2003 on National Education System Articles 1 \& 3, Jakarta: BP. Restindo Mediatama, 2003.

[79] Wallace, Belle, \& Eriksson, Gillian (Ed.), Diversity Gifted Education, International Perspective on Global Issues, New York: Routledge, 2006.

[80] Wirawan, Evaluation: Theory, Model, Standard, Application, and Profession, Jakarta: Rajawali Pers-Rajagrafindo Persada, 2011.

[81] Woolfolk, E. Anita. Educational Psychology. Tenth edition. USA: Pearson Education, Inc., 2007.

[82] Wortman, Camile, et.al., Psychology, Fifth Edition, Boston: McGraw-Hill College, 1999.

[83] Yin, Robert K.Studi Kasus (Design and Method), Jakarta: PT.Raja Grafindo Persada, 1997.

[84] Yulaelawati, Ella, Curriculum and Learning, Philosophy, Theory and Applications, Bandung: Pakar Raya, 2004.

[85] Zuhdi, Albaini, Acceleration Program, (Still Looking For The Ideal Form, Or Evaluation Of Its Implementation), (http://www.ditplb.or.id/2006/index.php?menu=profile\&pro=194), (diakses 7 November 2007). 